\section{Mystery ox finds its identity}

The kouprey, an enigmatic Asian ox believed to be a hybrid - and so, unworthy of conservation efforts - is in fact a distinct species related to the banteng (a wild ox $)^{1}$. The conclusion contradicts earlier findings ${ }^{2}$ that the horned beast is a cross between the banteng and domesticated zebu cattle.

First identified in 1937 and last spotted in the 1980s, the kouprey (Bos sauveli) has become a symbol for conservation in southeast Asia. Some experts think that it is already extinct.

Gary Galbreath, a biologist at Chicago's Field Museum in Illinois who concluded that the kouprey was a hybrid, told CBS News: "It is surely desirable not to waste time and money trying to locate or conserve a domestic breed gone wild." He based that conclusion on the observation that kouprey and banteng (Bos javanicus) shared several sequences of mitochondrial DNA.

Now, Alexandre Hassanin and Anne Ropiquet of the National Natural History Museum in Paris have sequenced three regions of mitochondrial DNA and five of non-coding nuclear DNA from seven related species, including kouprey. The pair found that kouprey have unique sequences of both mitochondrial and nuclear DNA. Their data suggest that kouprey should indeed be a conservation priority - if anyone can find one. Ewen Callaway

1. Hassanin, A. \& Ropiquet, A. Proc. R. Soc. B doi:10.1098/ rspb.2007.0830 (2007).

2. Galbreath, G. J., Mordacq, J. C. \& Weiler, F. H. J. Zool. 270, 561-564 (2006).

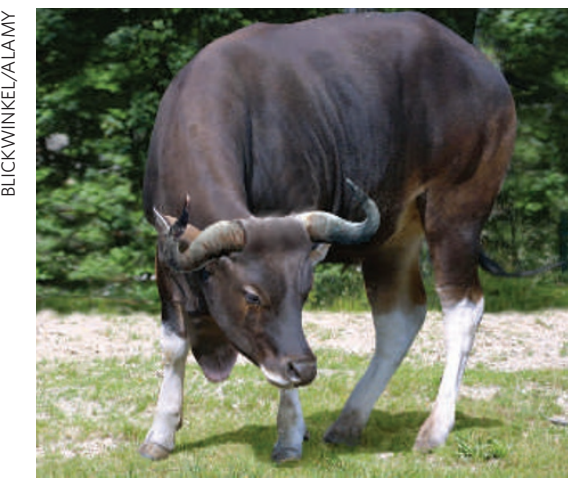

Cambodia's national emblem, the kouprey, is a distinct species of ox.

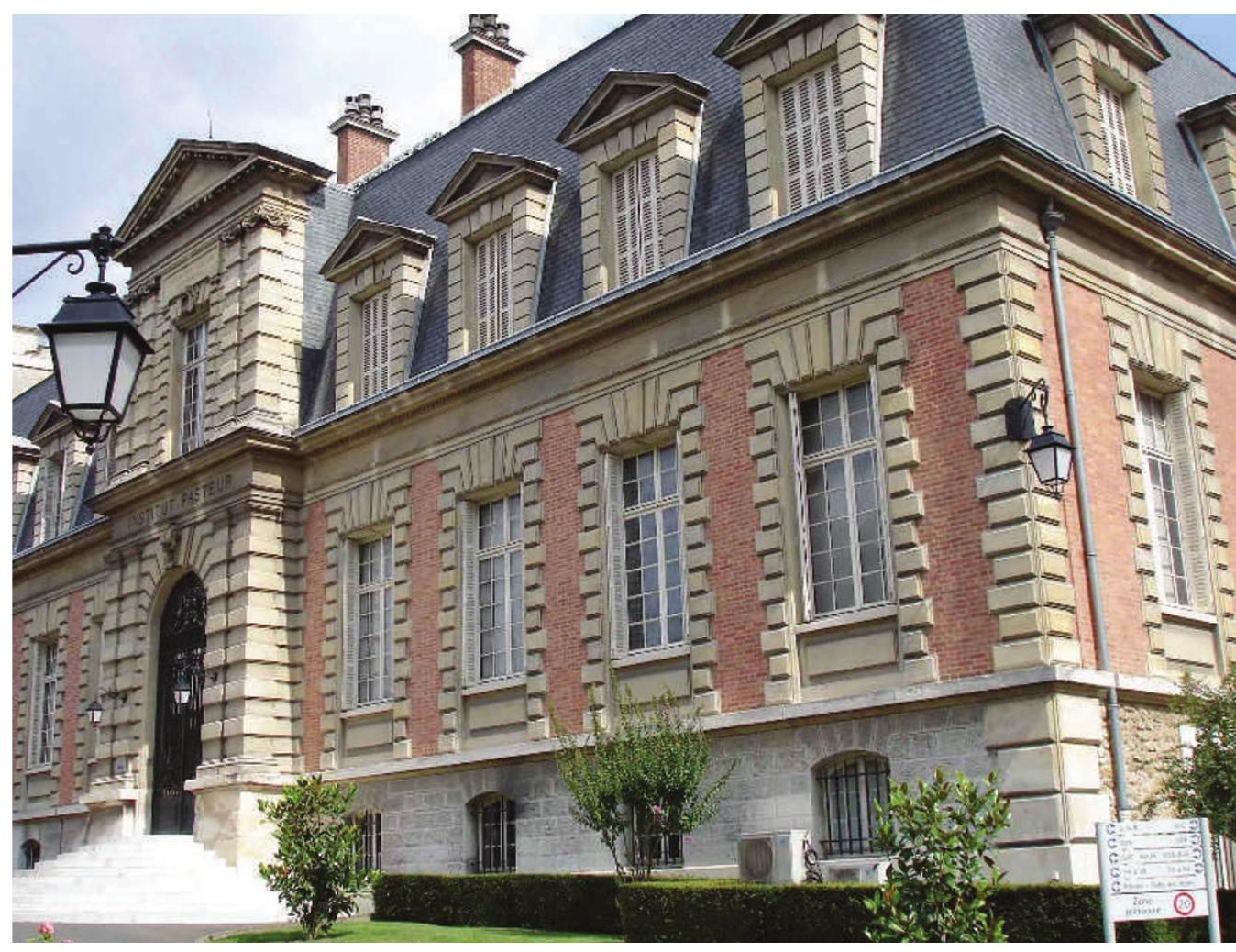

A reanalysis of research carried out at the Pasteur Institute casts doubt on a respected hypothesis.

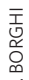

\title{
Long-held theory is in danger of losing its nerve
}

A suite of seminal neuroscience papers by Henri Korn of the Pasteur Institute in Paris allegedly contains a string of anomalies in data interpretation, according to a reanalysis of the papers, published this week in the Journal of Neurophysiolog $y^{1}$. But Korn and his co-authors contest this and are critical of the reanalysis, which appears in the same journal as many of Korn's original papers.

The papers, published over the past 25 years by Korn and his co-workers, including Donald Faber of the Albert Einstein College of Medicine in New York, concern the dynamics of the release of neurotransmitter chemicals at the synapse - the junction between nerve cells (see 'Theory of neurotransmitter release moves on'). They suggest that a single bouton (nerve terminus) releases only one quantum of transmitter per nerve impulse. This influential theory has major functional implications, but remains controversial.

A key finding underpinning their theory was based on electrophysiological studies of giant nerve cells in goldfish, called Mauthner cells. Korn and Faber claimed that the number of synaptic boutons counted by light microscopy was highly correlated with the number worked out from an analysis of the amplitudes of the electrical spikes triggered by the neurotransmitter $^{2}$. But their graph of the correlation, with data points lying on a nearly perfectly straight line, is "almost miraculous" given the noise and uncertainties in the underlying data, claims Jacques Ninio, a bioinformatician at the Ecole Normale Supérieure in Paris, who carried out the reanalysis.

Ninio extracted the data from graphs in the papers and recomputed them. "Several theoretical curves were simply not what Korn and co-workers claimed them to be," he says.

Ninio's conclusions add to similar allegations by two researchers who worked in Korn's laboratory - Nicole Ropert, now at the University of Paris Descartes, and Luca Turin, a former researcher for the CNRS, France's basicresearch agency, now at University College 